\title{
Organizational Unit
}

National Cancer Institute

\section{Source}

National Cancer Institute. Organizational Unit. NCI Thesaurus. Code C41167.

Org anizational unit like a laboratory, institute or consortium. 